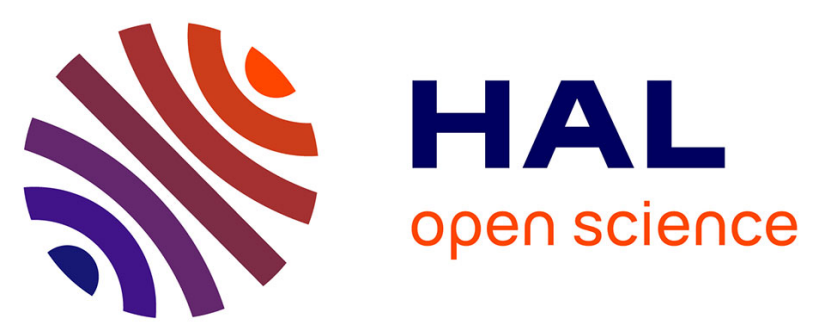

\title{
METHYLATION OF THE CPG SITES IN THE MYOTONIC DYSTROPHY LOCUS DOES NOT CORRELATE WITH CTG EXPANSION SIZE OR WITH THE CONGENITAL FORM OF THE DISEASE
}

Claudia Spits, Sara Seneca, Pierre Hilven, Inge Liebaers, Karen Sermon

\section{To cite this version:}

Claudia Spits, Sara Seneca, Pierre Hilven, Inge Liebaers, Karen Sermon. METHYLATION OF THE CPG SITES IN THE MYOTONIC DYSTROPHY LOCUS DOES NOT CORRELATE WITH CTG EXPANSION SIZE OR WITH THE CONGENITAL FORM OF THE DISEASE. Journal of Medical Genetics, 2010, 47 (10), pp.700. 10.1136/jmg.2009.074211 . hal-00557380

\author{
HAL Id: hal-00557380 \\ https://hal.science/hal-00557380
}

Submitted on 19 Jan 2011

HAL is a multi-disciplinary open access archive for the deposit and dissemination of scientific research documents, whether they are published or not. The documents may come from teaching and research institutions in France or abroad, or from public or private research centers.
L'archive ouverte pluridisciplinaire HAL, est destinée au dépôt et à la diffusion de documents scientifiques de niveau recherche, publiés ou non, émanant des établissements d'enseignement et de recherche français ou étrangers, des laboratoires publics ou privés. 


\section{METHYLATION OF THE CPG SITES IN THE MYOTONIC}

2 DYSTROPHY LOCUS DOES NOT CORRELATE WITH CTG

3 EXPANSION SIZE OR WITH THE CONGENITAL FORM OF THE

4 DISEASE.

5

6 Claudia Spits ${ }^{1}$, Sara Seneca ${ }^{2}$, Pierre Hilven ${ }^{1}$, Inge Liebaers ${ }^{1,2}$, Karen Sermon ${ }^{1}$

7

$81^{1}$ Department of Embryology and Genetics, Vrije Universiteit Brussel (VUB),

9 Laarbeeklaan 101, 1090, Brussels, Belgium

102 Centre for Medical Genetics, Universitair Ziekenhuis Brussel (UZ Brussel),

11 Laarbeeklaan 101, 1090, Brussels, Belgium

12

13 Corresponding author: Claudia Spits, Department of Embryology and Genetics, Vrije 14 Universiteit Brussel (VUB), Laarbeeklaan 101, 1090 Brussels, Belgium. Tel 32247746

15 34, Fax 32247766 60, e-mail claudia.spits@uzbrussel.be

$17 \quad$ ABSTRACT

18 We have studied the methylation status of the sequence 152 nucleotides upstream of

19 the CTG repeat of the DM1 locus in patients' peripheral blood. We used the methylation-

20 sensitive endonucleases SacII, HpaII and HhaI, followed by PCR. This allowed to

21 correlate the methylation status of each CTG allele with its size. Contrary to previous

22 findings (Steinbach P et al., 1988, Am.J.Hum.Genet. 62:278-285), only the SacII site is

23 often but not always differentially methylated amongst expanded CTG alleles.

24 Importantly, this methylation was not restricted to congenital DM1, nor to large

25 expansions, as it was also present in DM1 patients with a classical phenotype and various

26 expansion sizes. On the other hand, we did not find any methylated alleles on the HhaI 
and HpaII sites, as was reported by Steinbach et al, which is in line with the results of Shaw and collaborators (1993, J.Med.Genet. 30:189-192). The size range of the repeat expansions with methylation was from as small as 300 to as large as 2800 repeats.

\section{REPORT}

Myotonic dystrophy type 1 (DM1, [MIM 160900]) is a dominantly inherited multisystemic disorder, with an incidence of approximately 1 in 8000 individuals. DM1 has a complex phenotype, with symptoms including progressive skeletal muscle wasting, impaired muscle relaxation (myotonia), cardiac conduction defects resulting in arrhythmias, early-onset iridescent cataracts, insulin resistance and hyperinsulinemia (Harper, 2001). These symptoms are caused by several mechanisms, which include the aberrant processing of the DMPK mRNA, leading to decreased levels of DMPK (Krahe et al., 1995), toxic gain of function of the mRNA (Mankodi et al., 2000), decreased expression of the neighbouring SIX5 gene (Klesert et al., 1997; Thornton et al., 1997) and disrupted alternative splicing of numerous other genes (Ranum and Cooper, 2006).

DM1 is caused by a CTG expansion in the $3^{\prime}$ untranslated region of the DMPK gene located on chromosome 19q13.3. Expanded CTG tracts show both somatic and germinal instability; unaffected individuals have from 5 to 40 CTG repeats, whereas individuals with the disease carry more than 100 repeats. Disease severity and age of onset correlate with repeat size, and expansions of $>1500$ repeats often result in a severe congenital form of DM1.

CpG methylation has been suggested to play a role in the stability of repetitive sequences in general (Gourdon et al., 1997, Nichol and Pearson, 2002), and more particularly in the behaviour of the CTG repeat in the DM1 locus (Steinbach et al., 1998, Brock et al., 1999, Gorbunova et al., 2004) as well as in the pathogenesis of the disease (Shaw et al., 1993, Steinbach et al., 1998, Filippova et al., 2001 ).

The relationship between the semiology of the disease and the methylation of the CpG sites in the DM1 locus was first investigated by Shaw and collaborators (1993), who 
could not find any clear correlation between the methylation and the age of onset or the severity of the disease. On the other hand, Steinbach and coworkers found that several CpG sites close to the CTG repeat were fully methylated in blood samples containing expansions larger than 1000 repeats. They also reported that, since these expansions appeared as single well-defined signals on Southern blot, the methylation of these CpG sites would correlate with triplet repeat stability. This idea was later supported by in vitro and in silico work (Brock et al., 1999, Gorbunova et al., 2004, Gourdon et al., 1997, Nichol and Pearson, 2002). The work of Filippova built further on the idea that methylation would be related to the pathogenesis of congenital DM1 (CMD). The authors discovered that there are two binding sites for the zinc-finger protein CTCF flanking the CTG repeat, and that the hypermethylation of these sequences, which coincide with the region described by Steinbach and collaborators (1998), would be incompatible with the binding of the CTCF and its proper function mediating the inhibition of promoterenhancer interactions by insulator elements (Bell et al., 1999). Conversely, Libby and collaborators (2008) found that CpG methylation of CTCF binding sites may rather lead to repeat instability, instead of stability as previously suggested.

In this work we studied 8 of the $18 \mathrm{CpG}$ sites in 152 nucleotides upstream of the CTG repeat of the DM1 locus (see figure 1). These sites are part of the $\mathrm{CpG}$ sites investigated by Steinbach and collaborators and did not include the sites affecting the CTCF binding (Filippova et al., 2001). We did not investigate the distal SacII site, located over $1 \mathrm{~Kb}$ upstream of the CTG repeat, which Steinbach and collaborators reported as constitutively methylated, nor the HpaII and HhaI sites located in this same region. We analysed our samples in duplicate by methylation sensitive endonuclease digestion, followed by PCR. The PCRs were designed so that they included both the restriction site and the CTG repeat and were performed on small quantities of DNA. Consequently, smears could be resolved into individual bands, and sizing was much more accurate than by using Southern blot on total genomic DNA. Furthermore, it enabled us to correlate the methylation status with the exact length of each allele, which would not have been possible with Southern blot on total genomic DNA or bisulphite sequencing. It is 
important to notice that in the case of the HpaII restriction enzyme, the studied region contained 6 sites. This means that we could not distinguish the methylation state of each independent site, but could only asses whether at least one of the sites was unmethylated.

The aim of this study was to establish the threshold for the expansion size necessary for the hypermethylation of the CpG sites close to the CTG repeat and this within one DNA sample. We also aimed to investigate the possibility that hypermethylation is patient- or allele specific.

DNA samples from peripheral blood from 22 DM1 patients were digested with the methylation-sensitive restriction enzymes SacII, HhaI and HpaII (Biolabs, Westburg, Leusden, The Netherlands). Both digested and undigested samples were analysed by PCR. In the case of the SacII digested samples, we used the primer set indicated in figure 1 as SacII primer and reverse primer. The DNA input was of $200 \mathrm{pg}$. For the HhaI and HpaII samples, we used the HhaI-HpaII and the reverse primers. Initially, the DNA input was of $200 \mathrm{pg}$, but after the first results, DNA input was increased to $2 \mathrm{ng}$ to ensure the detection of possible uncleaved alleles present at a very low quantity. The PCR protocol was further performed as previously described (De Temmerman et al., 2008). The expansions were visualized by denaturing Southern blot using a GAC probe, and the size calculated by comparison to two molecular weight markers (markers VI and VII, Roche diagnostics, Vilvoorde, Belgium).

Table 1 shows the results for the 22 DM1 patients included in this study. The table outlines the results of the PCR before and after endonuclease cleavage by SacII, along with the disease status and inheritance of the mutation in all those patients for which these data were known. The cohort of patients includes cases of congenital DM1, infantile and classic DM1, both paternally and maternally inherited. The age at sampling ranges from birth to 43 years, and expansions were between 180 to 2800 repeats. Figure 2 shows an example of the Southern blot results after SacII restriction enzyme cleavage and PCR. The results for HhaII and HpaII cleavage, and the complete data for the SacII digestion can be found in the supplementary figures 1,2 and 3 . 
113 After HhaI endonuclease cleavage, none of the DNA samples showed amplification,

114 whereas the undigested samples worked as a positive control for the PCR. This meant 115 that all alleles were unmethylated, both the wild type alleles as well as all of the 116 expansions. We verified that the lack of amplification in the digested samples was not 117 due to DNA degradation by amplifying the material with a PCR for 4 short tandem 118 repeats located on chromosome 19q13.41, 19q13.33, 19p13.3 and 19p13.2 (tandem 119 repeats located using the database www.microsatellites.org). The primer sequences and 120 PCR conditions are available upon request. The results showed that the DNA was intact in 121 all samples, and proved that the restriction by HhaI had been specific for its target.

122 These results suggest that, contrary to the findings of Steinbach and collaborators, not 123 only is this CPG site constitutively unmethylated, but also that it is not necessarily 124 methylated in expansions larger than 1000 repeats or in congenital DM1 patients.

125 Identical results were obtained after cleavage with HpaII. Both the wild type and the expanded alleles were unmethylated (for at least one of the six HpaII sites in the

127 sequence) in all the samples studied. These results are in concordance with the findings 128 of Shaw and collaborators (1993) and contradict those of Steinbach and co-workers 129 (1998).

130 From our results it seems that of the CpG sites we studied the SacII site immediately 131 upstream of the repeat is the only one in the region that can be differentially methylated 132 between wild type alleles, which are never methylated, and expanded alleles, which may 133 be methylated. Our data are difficult to harmonize with the previously published study 134 (Steinbach et al., 1998). We did not find a correlation between the methylation status of 135 this site on one hand and the allele size or on the other hand with the presence of a 136 smear on the Southern blot -indicative of tripet repeat instability- , as was suggested by 137 Steinbach et al. Alleles as small as 400 repeats could be methylated (patient 20), and 138 alleles of 1600 repeats unmethylated (patient 8), indicating that there is no correlation 139 between the allele size and the methylation status. We found several patients showing 140 intermediate methylation patterns (some alleles were methylated while others were not), 141 and even patients without any methylation at this site. A patient could present a smear 
142 in which all alleles appeared to be methylated (i.e. patient 7), indicating that the

143 methylation status apparently does not correlate with the stability of the repeat.

144 However, it is clear that the presence of CTG length mosaicism either with or without

145 methylation does not necessarily make one the cause or effect of the other. The time

146 during which one occurred may or may not have coincided with the other. Furthermore,

147 the link between methylation of this site and congenital DM1 does not seem to be as

148 strict as previously assumed. It is true that both congenital DM1 cases analysed here

149 showed methylation of the SacII site in all the expanded CTG alleles (patients 4 and 6),

150 but non-congenital DM1 patients also presented it (patients 5 and 7). Furthermore, we

151 did not find the correlation previously described (Steinbach et al., 1998) between the

152 methylation of the SacII site and of the HhaI and HpaII sites, since we never found

153 methylation in the latter two, not even in the congenital DM1 patients. The fact that we

154 did not find a methylation pattern specific to the CMD patients contradicts the hypothesis

155 that differential methylation may be responsible for the distinct features of CMD by

156 modulating the binding of CTCF in the DM1 locus (Flippova et al., 2001). It is, however,

157 important to bear in mind that we did not study the methylation of all the CpG sites

158 present in the CTCF binding sites, and that methylation may still play an important role in

159 the pathogenesis of DM1.

160 These discordances do not seem attributable to incomplete restriction or technical

161 differences. In the works of Shaw et al. (1993) and Steinbach et al. (1998), as in ours,

162 incomplete restriction would have been detected by the incomplete cleavage of the wild

163 type allele. To ensure that the results for HpaII and HhaI were not due to the

164 degradation of the samples after restriction, we confirmed the presence of intact DNA by

165 PCR for microsatellite markers. The fact that in our work we analysed PCR products by

166 Southern blot, whereas Shaw et al. (1993) and Steinbach et al. (1998) performed direct

167 Southern blotting of the restricted DNA only adds to the resolution of the expanded

168 alleles. Furthermore, it is possible that our method is more sensitive in picking up a few

169 unrestricted alleles. Nevertheless, for the HhaI and HpaII digests, we never found any

170 uncleaved allele. 
171 In the work of Shaw et al (1993) it is suggested that the patient's age might play a role

172 on the methylation levels in CMD. The authors suggest that, since their CMD patients

173 were rather of mature age, the methylation could have been lost. It is important to bear

174 in mind that these authors were investigating a possible relationship between imprinting

175 of the DM1 locus and CMD, and hypothesized that this imprinting would only be of

176 importance in utero, and would be subsequently lost after birth. In Steinbach's paper,

177 the oldest CMD patient is 24 years, and shows full methylation of the expanded allele for

178 all the SacII, HhaI and HpaII sites. Shaw et al. (1993) did not mention the exact age of

179 the patients, but if they were older than 24 years, their hypothesis would harmonize the

180 difference in results between Shaw and Steinbach's papers, but not with ours, where the

181 two CMD patients were very young, and showed no methylation for the HhaI and HpaII

182 sites. An age effect on the classical DM1 patients can be ruled out, as both Steinbach's

183 work as ours has patients of all ages (Steinbach's range was 19-62, ours 4-45 years).

184 Furthermore, there does not seem to be a parent of origin effect.

185 In conclusion, we have studied the methylation status of the proximal sequence 186 upstream of the CTG repeat of the DM1 locus. From our results, we establish that, 187 contrary to previous findings, only one of the studied sites is differentially methylated in

188 wild type and expanded CTG alleles, and that this methylation does not strictly correlate 189 with the length of the allele, nor with the disease status of the patient. Further research 190 on this topic is necessary to elucidate the reasons for the discrepancy with some of the 191 previously published results.

\section{AKNOWLEDGEMENTS}

193 The authors wish to thank their colleagues at the Centre for Medical Genetics for the 194 fruitful collaboration, and Prof. C.E. Pearson for his constructive comments on the 195 manuscript. This work has been supported by grants from the Fund for Scientific 196 Research Flanders (Fonds voor Wetenschappelijk Onderzoek (FWO) Vlaanderen). CS is a 197 postdoctoral fellow at the FWO Vlaanderen. 


\section{License for publication}

200 The Corresponding Author has the right to grant on behalf of all authors and does grant

201 on behalf of all authors, an exclusive licence (or non exclusive for government

employees) on a worldwide basis to the BMJ Publishing Group Ltd to permit this article (if

accepted) to be published in Journal of Medical Genetics and any other BMJPGL products

and sublicences such use and exploit all subsidiary rights, as set out in our licence

205

(http://group.bmj.com/products/journals/instructions-for-authors/licence-forms).

\section{Competing interests}

None declared

\section{REFERENCES}

Bell, A.C., West, A.G., and Felsenfeld, G. (1999) The protein CTCF is required for the enhancer blocking activity of vertebrate insulators. Cell. 98,387-96.

Brock, G. J., Anderson, N. H., and Monckton, D. G. (1999). Cis-acting modifiers of expanded CAG/CTG triplet repeat expandability: associations with flanking GC content and proximity to $\mathrm{CpG}$ islands. Hum. Mol. Genet. 8, 1061-1067.

De Temmerman, N., Seneca, S., Van Steirteghem, A., Haentjens, P., Van der Elst, J., Liebaers, I., and Sermon, K.D. (2008). CTG repeat instability in a human embryonic stem cell line carrying the myotonic dystrophy type 1 mutation. Mol. Hum. Reprod. 14, 40512.

Filippova, G. N., Thienes, C. P., Penn, B. H., Cho, D. H., Hu, Y. J., Moore, J. M., Klesert, T. R., Lobanenkov, V. V., and Tapscott, S. J. (2001). CTCF-binding sites flank CTG/CAG repeats and form a methylation-sensitive insulator at the DM1 locus. Nat. Genet. 28, 335-343.

Gorbunova, V., Seluanov, A., Mittelman, D., and Wilson, J. H. (2004). Genome-wide demethylation destabilizes CTG.CAG trinucleotide repeats in mammalian cells. Hum. Mol. Genet. 13, 2979-2989.

Gourdon, G., Dessen, P., Lia, A. S., Junien, C., and Hofmann-Radvanyi, H. (1997). Intriguing association between disease associated unstable trinucleotide repeat and CpG island. Ann. Genet. 40, 73-77.

Harper, P.S. (2001). Myotonic Dystrophy. $3^{\text {rd }}$ edn. WB Saunders, London, UK.

Klesert, T.R., Otten, A.D., Bird, T.D., and Tapscott, S.J. (1997). Trinucleotide repeat expansion at the myotonic dystrophy locus reduces expression of DMAHP. Nat. Genet. 16,402-6. 
Krahe, R., Ashizawa, T., Abbruzzese, C., Roeder, E., Carango, P., Giacanelli, M., Funanage, V. L., and Siciliano, M. J. (1995). Effect of myotonic dystrophy trinucleotide repeat expansion on DMPK transcription and processing. Genomics 28, 1-14.

Libby, R.T., Hagerman, K.A., Pineda, V.V., Lau R, Cho, D.H., Baccam, S.L., Axford, M.M., Cleary, J.D.,Moore, J.M., Sopher, B.L. et al. (2008). CTCF cis-regulates trinucleotide repeat instability in an epigenetic manner: a novel basis for mutational hot spot determination. PLoS Genet. 4:e1000257.

Mankodi, A., Logigian, E., Callahan, L., McClain, C., White, R., Henderson, D., Krym, M., and Thornton, C. A. (2000). Myotonic dystrophy in transgenic mice expressing an expanded CUG repeat. Science 289, 1769-1773.

Nichol, K. and Pearson, C. E. (2002). CpG methylation modifies the genetic stability of cloned repeat sequences. Genome Res. 12, 1246-1256.

Ranum, L. P. and Cooper, T. A. (2006). RNA-Mediated Neuromuscular Disorders. Annu.

256 Rev. Neurosci.

257

Shaw, D. J., Chaudhary, S., Rundle, S. A., Crow, S., Brook, J. D., Harper, P. S., and Harley, H. G. (1993). A study of DNA methylation in myotonic dystrophy. J. Med. Genet. $30,189-192$.

Steinbach, P., Glaser, D., Vogel, W., Wolf, M., and Schwemmle, S. (1998). The DMPK gene of severely affected myotonic dystrophy patients is hypermethylated proximal to the largely expanded CTG repeat. Am. J. Hum. Genet. 62, 278-285.

Thornton, C.A., Wymer, J.P., Simmons, Z., McClain, C., and Moxley, R.T. 3rd (1997). Expansion of the myotonic dystrophy CTG repeat reduces expression of the flanking DMAHP gene. Nat. Genet. 16,407-9.

\section{FIGURE LEGENDS}

Figure 1. Schematic overview of the sequence analyzed in this study and its relationship to the genomic regions studied by Shaw et al (1993) and Steinbach et al (1998). The figures are modified versions of the original figures found in the respective publications. A: Genomic region studied by Shaw et al.(1993). Three fragments were created using EcoRI and EcoRV, and then restricted by HpaII. The results showed that at least some of the HpaII sites contained unmethylated cytosines, independently of the form of the disease or expansion size. B: Genomic region studied by Steinbach et al. (1998). The samples were restricted using combinations of SacI and HindIII, and SacII, HpaII or HhaI. The results showed that the upstream SacII site was constitutively methylated, and the downstream SacII site only methylated on very largely expanded alleles of patients with congenital DM1. The HpaII and HhaI sites were also all 
280 methylated in these patients. C: Sequence studied in this paper. Genomic DNA was

281 restricted using SacII, HpaII or HhaI and amplified by PCR using the primers indicated on

282 the sequence as arrows. The highlighted sequence corresponds to the CTCF binding site

2831 (Fillippova et al., 2001). The results showed no correlation between the methylation of

284 the SacII site and the disease status of the patient or the expansion size. No methylation

285 of the HhaI site was detected, and the results for HpaII suggested that there was at least

286 always one unmethylated site present in the sequence.

287 Figure 2. Example of the Southern blot results after SacII restriction enzyme cleavage and PCR. Lanes 1, 2, 3, 4 and 5 show restricted samples, lanes 1', 2', 3', 4' and 5' are

289 the same DNA samples, but unrestricted. These numbers correspond also to the patient

290 identification numbers found in table 1 . The lane marked with MWM contains the

291 molecular weight marker VII (Roche Diagnostics, Vilvoorde, Belgium). The lane numbers

292 correspond to the patient numbers. Unrestricted samples still contain the wild type allele

293 (wt), whereas in the restricted samples, the wt is completely cleaved. This can be used

294 as an internal restriction control.

295 Supplementary figures 1, 2 and 3. Raw data of the Southern blot analysis of the 296 PCRs after restriction enzyme digestion of the patient's DNA samples. Figure 1 shows the 297 results for the SacII cleavage, figure 2 for the HpaII cleavage, and figure 3 for the HhaI 298 cleavage. All Southern blots contain the PCR products of restricted and unrestricted DNA 299 samples, for comparison and as PCR control. The lanes are labeled with the patient's 300 identification numbers. When the number is followed by a ' $d$ ', it is a digested sample. All 301 blots show one or two molecular weight markers. On the left side, molecular weight 302 marker VI is shown, on the right, marker VII of Roche Diagnostics (Vilvoorde, Belgium).

303 Some samples have been analyzed in duplicate on the same blot, and in some cases a

304 replicate can be found on another blot. In the case of the HpaII and HhaI cleavage, the 305 blots show smears in the control lanes because the PCRs were performed with a higher 306 input to ensure the detection of possible uncleaved alleles present in a low quantity.

307 Nevertheless, none or the digested samples showed any amplification, revealing that 308 they all contained unmethylated sites. The signal at the lower end of the blot corresponds 
309 to the wild type allele. Its full cleavage serves as an internal control for the digestion, as

310 it is assumed to be always unmethylated. In some lanes, heteroduplexes can be seen as

311 a signal between the wild type and the expanded allele.

312 


\section{TABLE}

\begin{tabular}{|c|c|c|c|c|c|c|}
\hline Patient & $\begin{array}{l}\text { Disease status } \\
\text { and origin of } \\
\text { mutation }\end{array}$ & $\begin{array}{l}\text { Age at } \\
\text { sampling }\end{array}$ & $\begin{array}{l}\text { Expansion size } \\
\text { (repeats) }\end{array}$ & $\begin{array}{l}\text { Description of the } \\
\text { expansion }\end{array}$ & $\begin{array}{l}\text { Alleles after SacII } \\
\text { digestion }\end{array}$ & $\begin{array}{l}\text { Description of the } \\
\text { alleles after SacII } \\
\text { digestion }\end{array}$ \\
\hline 1 & DM, paternal & 33 & $900-2800$ & $\begin{array}{l}\text { Numerous discrete } \\
\text { bands }\end{array}$ & $900-2800$ & $\begin{array}{l}\text { Numerous discrete } \\
\text { bands: full methylation }\end{array}$ \\
\hline 2 & Unknown & 30 & $400-1200$ & Smear & Fully cleaved & Fully unmethylated \\
\hline 3 & DM, paternal & 33 & $200-400$ & $\begin{array}{l}\text { Two groups of very } \\
\text { close bands }\end{array}$ & Fully cleaved & Fully unmethylated \\
\hline 4 & $\begin{array}{l}\text { CMD, probably } \\
\text { maternal }\end{array}$ & 3 months & 1400 & One band & 1400 & $\begin{array}{l}\text { One band: full } \\
\text { methylation }\end{array}$ \\
\hline 5 & DM, paternal & 41 & $300-900$ & $\begin{array}{l}\text { Two groups of very } \\
\text { close bands }\end{array}$ & $300-900$ & $\begin{array}{l}\text { Two groups of very } \\
\text { close bands: full } \\
\text { methylation }\end{array}$ \\
\hline 6 & CMD, maternal & Newborn & $700-1300$ & $\begin{array}{l}\text { Smear with } \\
\text { predominant band at } \\
1300\end{array}$ & $700-1300$ & $\begin{array}{l}\text { Smear with } \\
\text { predominant band at } \\
\text { 1300: full methylation }\end{array}$ \\
\hline 7 & Unknown & 4 & $700-1300$ & $\begin{array}{l}\text { Smear with } \\
\text { predominant band at } \\
1300\end{array}$ & $700-1300$ & $\begin{array}{l}\text { Smear with } \\
\text { predominant band at } \\
\text { 1300: full methylation }\end{array}$ \\
\hline 8 & DM, maternal & 20 & $700-1600$ & $\begin{array}{l}\text { Smear with } \\
\text { predominant allele } \\
\text { at } 1600\end{array}$ & 860 & $\begin{array}{l}\text { One band: partial } \\
\text { methylation }\end{array}$ \\
\hline 9 & Unknown & Unknown & $200-500$ & Smear & Fully cleaved & Fully unmethylated \\
\hline 10 & DM, paternal & 33 & $700-1600$ & $\begin{array}{l}\text { Smear with } \\
\text { predominant allele } \\
\text { at } 1600\end{array}$ & $700-1160$ & $\begin{array}{l}\text { Bands of } 700,990,840 \\
\text { and } 1160 \text { : partial } \\
\text { methylation }\end{array}$ \\
\hline 11 & DM, maternal & 30 & $600-1200$ & Smear & $680-1170$ & $\begin{array}{l}\text { Bands of } 680 \text { and } 1170: \\
\text { partial methylation }\end{array}$ \\
\hline 12 & DM, paternal & 24 & $200-480$ & Smear & Fully cleaved & Fully unmethylated \\
\hline 13 & $\begin{array}{l}\text { DM, probably } \\
\text { maternal }\end{array}$ & 33 & $200-480$ & Smear & Fully cleaved & Fully unmethylated \\
\hline 14 & DM, maternal & 27 & $680-900$ & Smear & $680-860$ & $\begin{array}{l}\text { Bands of } 680 \text { and } 860: \\
\text { partial methylation }\end{array}$ \\
\hline 15 & DM, paternal & 45 & $500-1300$ & Smear & $840-990$ & $\begin{array}{l}\text { Bands of } 840 \text { and } 990: \\
\text { partial methylation }\end{array}$ \\
\hline 16 & DM, paternal & 38 & $500-1300$ & Smear & Fully cleaved & Fully unmethylated \\
\hline 17 & Unknown & 43 & $500-1650$ & Smear & 1300 & $\begin{array}{l}\text { One band: partial } \\
\text { methylation }\end{array}$ \\
\hline 18 & Unknown & 30 & $220-370$ & Smear & Fully cleaved & Fully unmethylated \\
\hline 19 & DM, maternal & 29 & $250-1400$ & Smear & $850-1000$ & $\begin{array}{l}\text { Bands of } 850 \text { and } 1000: \\
\text { partial methylation }\end{array}$ \\
\hline 20 & DM & Unknown & $180-2200$ & Smear & $400-1700$ & $\begin{array}{l}\text { discrete bands of } 400, \\
900 \text { and } 1700: \text { partial } \\
\text { methylation }\end{array}$ \\
\hline 21 & Unknown & Unknown & $300-2600$ & Smear & $600-2600$ & $\begin{array}{l}\text { discrete bands of } 600, \\
950,1200,1500,1600 \\
\text { and } 2600: \text { partial } \\
\text { methylation }\end{array}$ \\
\hline 22 & $\begin{array}{l}\text { Infantile form, } \\
\text { maternal }\end{array}$ & 14 & $1000-2600$ & Smear & 1300 & $\begin{array}{l}\text { One band: partial } \\
\text { methylation }\end{array}$ \\
\hline
\end{tabular}

314

DM: disease onset is not congenital, CMD: disease onset is congenital.

Full methylation indicates that all alleles appeared to carry a methylated SacII site. 
A

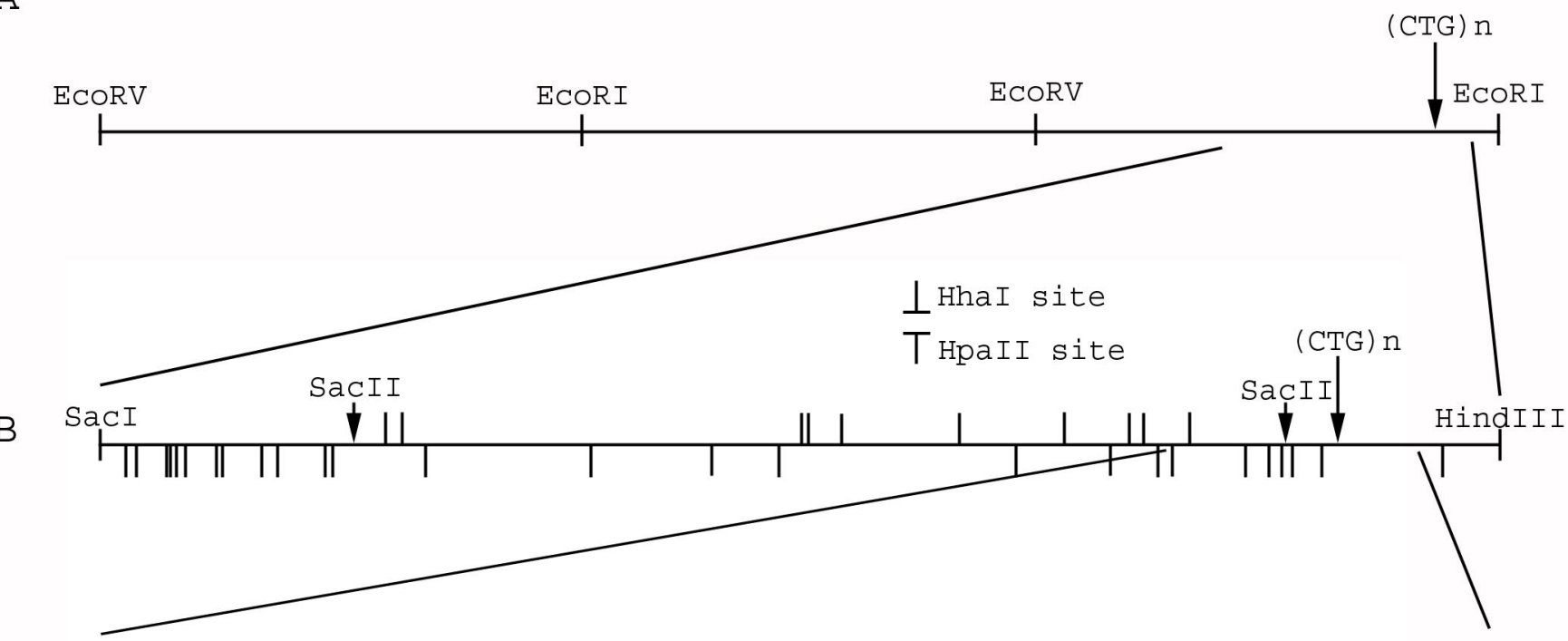

\section{Hpa I I}

Hha I

CCGTTGGAAGACTGAGTGCDCGGGGCACGGCACAGAAGCCGCG|CCCACCGCCTGCCAGTTCACAACCGCTCCGAG HhaI-HpaII primer HpaII

HpaII

Hpa I I CGTGGGTCTCCGCCCAGCTCCAGTCCTGTGATd|CGGGCCCGCCCCCTAGCGGdCGGGGAGGGAGGGGClCGGGTCC

\section{SacII primer $\longrightarrow$ HpaII}

SacII

GCGjdicGGCGAACGGGGCTCGAAGGGTCCTTGTAGClCGGGAATGCTGCTGCTGCTGCTGCTGCTGCTGCTGCTGC Hpa I I

TGCTGCTGCTGGGGGGATCACAGACCATTTCTTTCTTTCGGCCAGGCTGAGGCCCTGACGTGGATGGGCAAACTG CAGGCCTGGGAAG 
Patients

$900 \stackrel{\mathrm{CTG}}{\longrightarrow}$

$400 \stackrel{\text { CTG }}{\longrightarrow}$

$200 \stackrel{\text { CTG }}{\longrightarrow}$

$\stackrel{\text { wt }}{\longrightarrow}$ 
Supplementary figure 1: SacII digested DNA samples.
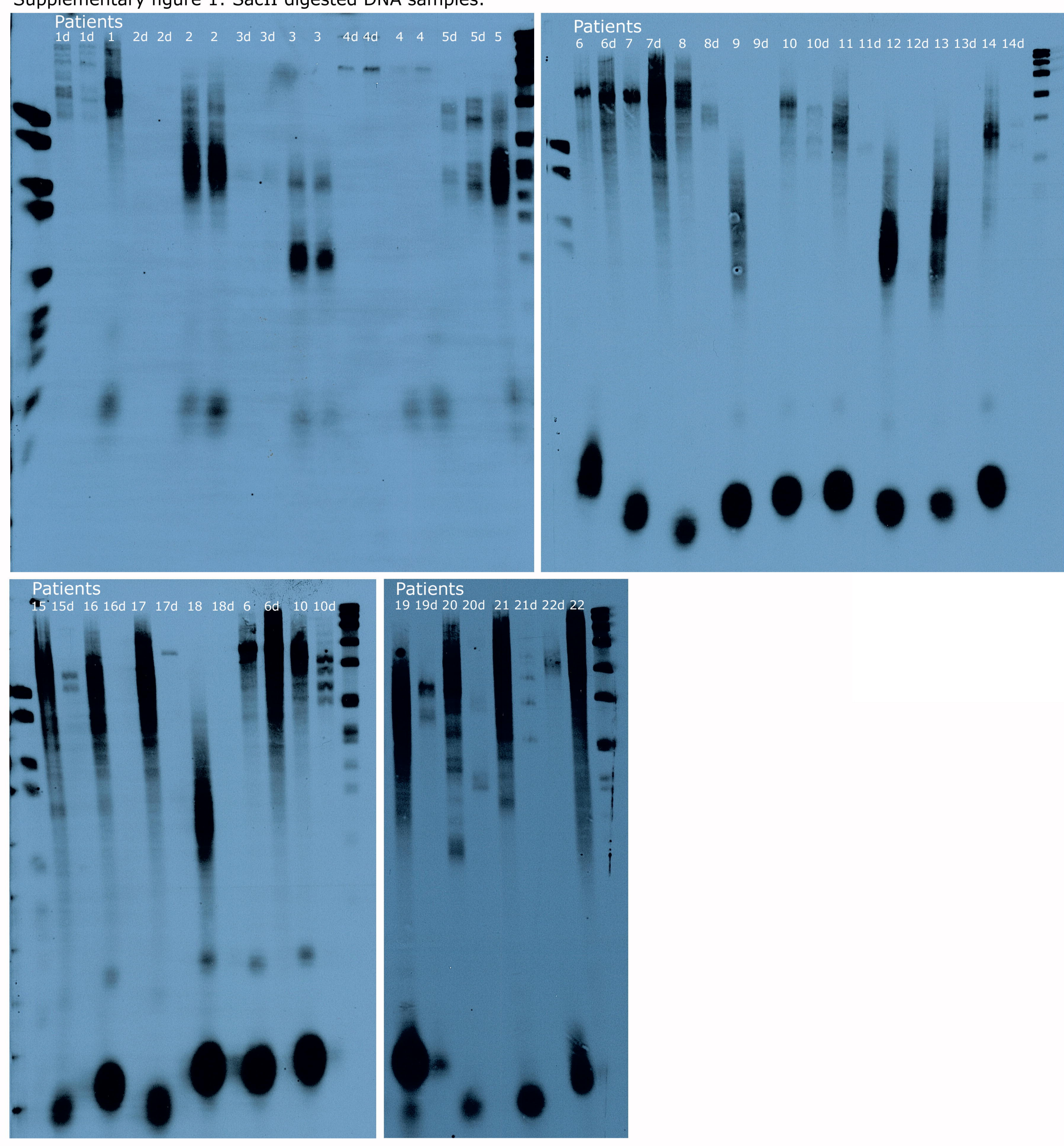


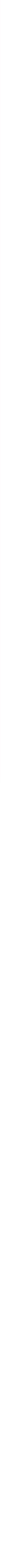




\section{Supplementary figure 3: HhaI digested DNA samples.}

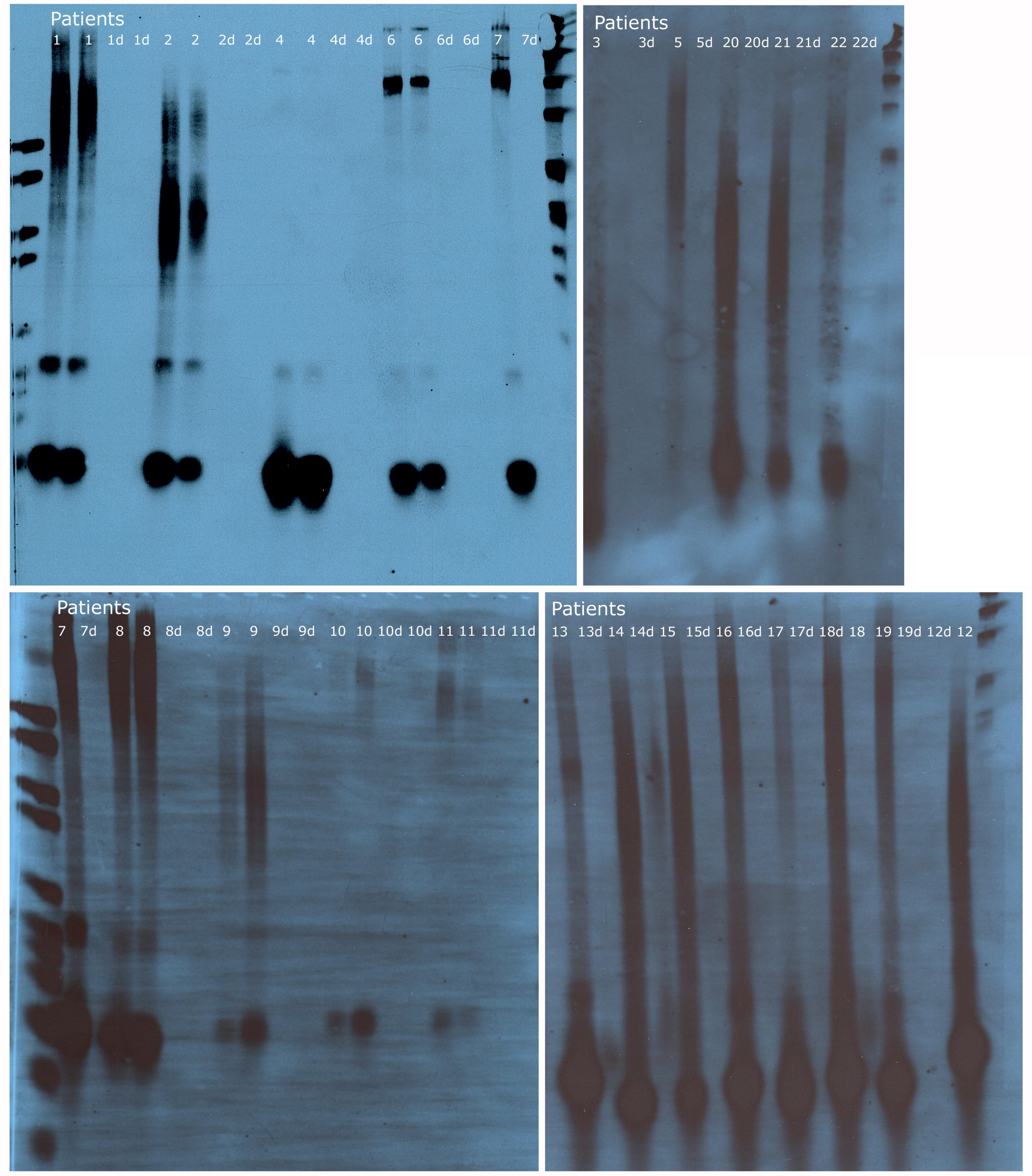

